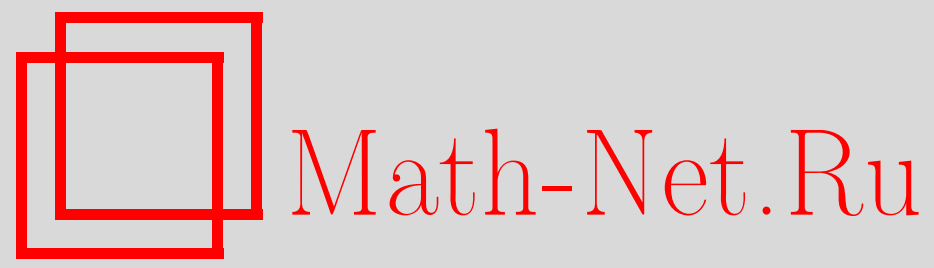

Информационное сообщение о мини-симпозиуме CTCrypt 2012, Mameм. вопр. криптогр., 2013, том 4, выпуск 2, 43

DOI: https://doi.org/10.4213/mvk80

Использование Общероссийского математического портала Math-Net.Ru подразумевает, что вы прочитали и согласны с пользовательским соглашением

http://www.mathnet.ru/rus/agreement

Параметры загрузки:

IP: 3.85 .5 .30

26 апреля 2023 г., 12:44:53 


\section{ИНФОРМАЦИОННОЕ СООБЩЕНИЕ}

\section{О мини-симпозиуме СТCrypt 2012}

2 июля 2012 года в Нижнем Новгороде в рамках VII Международного симпозиума по компьютерным наукам в России (7th International Computer Science Symposium in Russia, CSR-2012) состоялся мини-симпозиум «Современные тенденции в криптографии» (Current Trends in Cryptology, CTCrypt-2012), организованный техническим комитетом по стандартизации ТК 26 «Криптографическая защита информации», Академией криптографии Российской Федерации и Нижегородским государственным университетом имени Н. И. Лобачевского при финансовой поддержке ОАО «ИнфоТеКС». Программа мини-симпозиума включала 16 докладов, тематика которых охватывала следующие вопросы:

- исследование конкретных криптографических алгоритмов, в том числе являющихся национальными и международными стандартами (восемь докладов);

- практическая реализация криптографических алгоритмов (три доклада);

- математический аппарат криптографических исследований (пять докладов).

В настоящем выпуске журнала публикуется приветственное слово сопредседателя программного комитета CTCrypt-2012 вице-президента Академии криптографии Российской Федерации В.Н.Сачкова и избранные расширенные тезисы докладов мини-симпозиума. С остальными материалами можно ознакомиться на веб-странице мини-симпозиума http://tc26.ru/CTCrypt/2012/. 